\title{
Ecological restoration of fly ash-dumped area: Challenges and Opportunities
}

\author{
Swati Yadav ${ }^{1}$, VC Pandey ${ }^{2}$, and Lal singh ${ }^{1}$ \\ ${ }^{1}$ National Environmental Engineering Research Institute CSIR \\ ${ }^{2}$ Babasaheb Bhimrao Ambedkar University
}

April 7, 2021

\begin{abstract}
Fly ash (FA) is the $80 \%$ of coal burnt by-product of thermal power plants (TPPs), its disposal in landfills causes environmental and health issues. The amount of FA production is increasing continuously to fulfil the worldwide energy for demand, which possibly never find a practically safe method for FA dumping. Its fine particle size disperses in the air and causes air pollution and water pollution is resulted due to slurry erosion from FA dumps and contamination by leachate. Health issues and environmental concerns due to fly ash landfills/dumpsites can be prohibited by covering with phytoaccumulator plant species. Limitations of plant growth in FA includes alkaline $\mathrm{pH}$, contain metals such as $\mathrm{Cr}, \mathrm{Cd}, \mathrm{As}, \mathrm{Hg}$ and $\mathrm{Pd}$, toxic level of $\mathrm{B}$, pozzolanic properties of FA and lack of microbial activity. Generally, the phytoremediation process is slow therefore, to accelerate the phytoremediation process FA require organic amendments and bio-fertilizers. This article focuses on the role of naturally occurring plants in stabilization of FA dumpsite and physiochemical changes in FA. This review summarises the different holistic approaches of rehabilitations of FA landfills and also compiles how to convert FA landfills into useful landfills for bioenergy productions. Utilization of organic matter and industrial waste has been proved to provide essential nutrients for plant establishment and heavy metal accumulation. The outcomes of this learning are beneficial for classifying site-specific ecological restoration of FA landfills through holistic approach.
\end{abstract}

\section{Hosted file}

Manuscript.pdf available at https://authorea.com/users/406279/articles/516995-ecologicalrestoration-of-fly-ash-dumped-area-challenges-and-opportunities

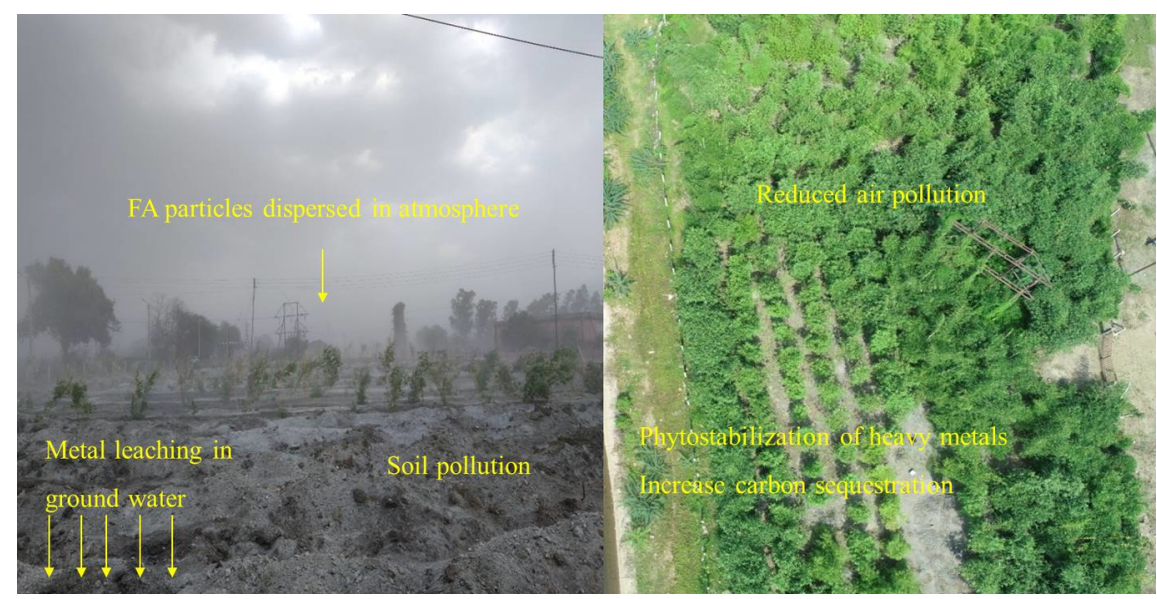




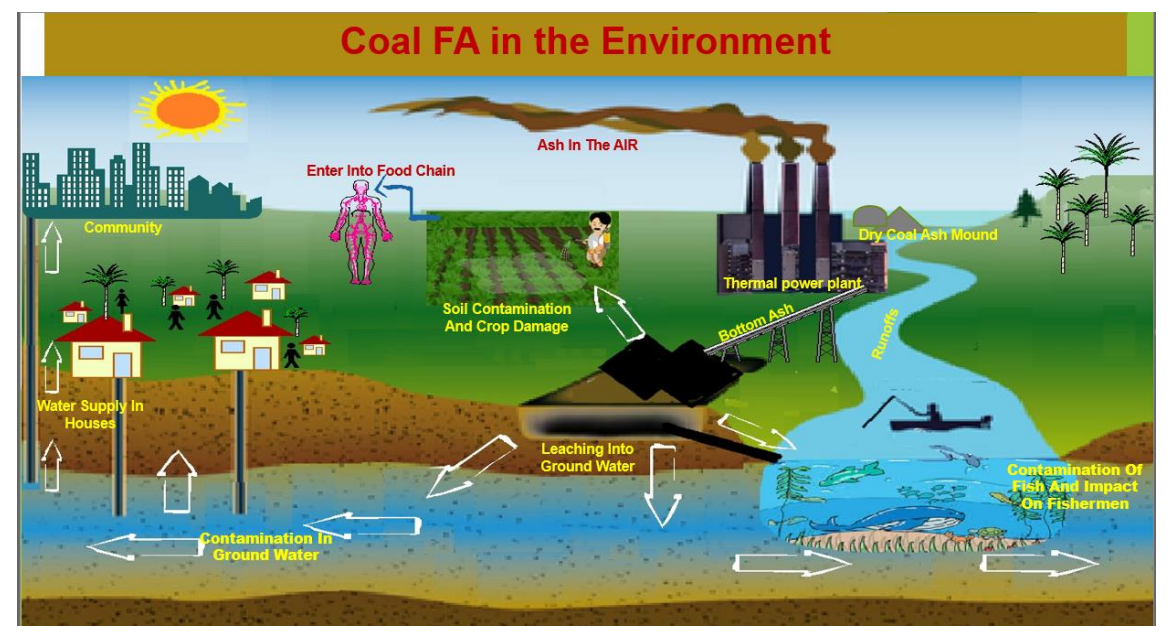

\section{Hosted file}

Table 1.pdf available at https://authorea.com/users/406279/articles/516995-ecologicalrestoration-of-fly-ash-dumped-area-challenges-and-opportunities

\section{Hosted file}

Table 2.pdf available at https://authorea.com/users/406279/articles/516995-ecologicalrestoration-of-fly-ash-dumped-area-challenges-and-opportunities

\section{Hosted file}

Table 3.pdf available at https://authorea.com/users/406279/articles/516995-ecologicalrestoration-of-fly-ash-dumped-area-challenges-and-opportunities

\section{Hosted file}

Table 4.pdf available at https://authorea.com/users/406279/articles/516995-ecologicalrestoration-of-fly-ash-dumped-area-challenges-and-opportunities 